\title{
Pergeseran Penggunaan Kata Sapaan oleh Generasi Milenial Banjar di Kota Banjarbaru
}

\author{
Eka Suryatin \\ Balai Bahasa Kalimantan Selatan \\ ekasuryatin@yahoo.co.id
}

\section{Article Info}

\section{Article history:}

Submitted Jan 25, 2020

Revised Feb 19, 2020

Accepted April 09, 2020

Published April 30, 2020

\section{Keywords:}

shift

greeting words

banjar language

mileniall generation

\begin{abstract}
This study was designed to describe the change in greeting words used by the Millennial Floods in Banjarbaru City and the factors that influence them. This study used descriptive qualitative method. Data collection by refer to the method. Data analysis was performed using the matching method and the advanced technique of the Determination of the Determination Element (PUP) technique. The data used consists of greetings used by the millennial generation of Banjar in Banjarbaru. The research data source consisted of utterances delivered by the Banjar millennial generation in Banjarbaru. The results showed the greeting words used by the Banjar millennial generation in Banjarbaru City increased rotation. Occurs when family runs, kinship, and intimacy. The most shifted form of greeting words occurs in the realm of the family, namely the immediate family. The displacement language used by the millennial flood generation, namely Indonesian and languages (Arabic and English) even has the Banjar language itself. Factors that influence change, namely the existence of urbanization, the progress of science and technology, the language of prestige, and generation over.
\end{abstract}

\section{Corresponding Author:}

Eka Suryatin,

Balai Bahasa Kalimantan Selatan

Jalan A. Yani No. KM 32, Guntung Payung

Kec. Landasan Ulin, Kota Banjar Baru, Kalimantan Selatan 70712

Email: ekasuryatin@yahoo.co.id

\section{PENDAHULUAN}

Kota Banjarbaru merupakan salah satu kota di wilayah Kalimantan Selatan yang mengalami perkembangan pembangunan yang pesat. Pesatnya pembangunan di kota Banjarbaru didukung dengan pendidikan serta ekonomi masyarakat yang maju. Perkembangan pembangunan yang pesat itu membuat banyak masyarakat dari berbagai suku tinggal di kota tersebut. Masyarakat yang tinggal di kota Banjarbaru ada yang berasal dari suku Jawa, Batak, Bali, Bugis, dan lainnya. Bahkan penduduk asli Banjar yang tinggal di kota lain juga pindah untuk tinggal di kota Banjarbaru.

Adanya berbagai suku atau multietnik yang mendiami kota Banjarbaru berpengaruh pada bahasa yang digunakan. Sebagian masyarakat masih ada yang mempertahankan bahasanya dan ada juga yang menggeser bahasanya. Pemertahanan bahasa terjadi apabila masyarakat tutur tetap menggunakan bahasanya di tengah-tengah bahasa yang lain. Hal ini sesuai dengan pendapat (Chaer \& Agustina, 1995, hal. 5) yang menyatakan bahwa pemertahanan bahasa (language maintainance) menyangkut masalah sikap atau penilaian terhadap suatu bahasa untuk tetap menggunakan bahasanya tersebut di tengah-tengah bahasa yang lain. Sementara itu, pergeseran bahasa akan terjadi apabila 
masyarakat tuturnya mengganti atau meninggalkan bahasa mereka. (Sumarsono, 2011, hal. 231) berpendapat bahwa pergeseran bahasa (language shifting) dapat terjadi ketika warga gugup secara kolektif memilih bahasa baru.

Seiring berkembangnya zaman adanya pengaruh globalisasi dan canggihnya alat teknologi membuat masyarakat kota Banjarbaru khususnya generasi muda yang tinggal di kota Banjarbaru mendapat dampak dari kejadian itu. Generasi muda, era perkembangan teknologi yang dikenal dengan generasi milenial semakin asing dengan bahasa daerah mereka sendiri, mereka lebih memilih bahasa Indonesia, bahasa asing, dan bahasa gaul. Hal ini sama seperti yang diungkapkan oleh (Putri, 2018, hal. 87) dalam hasil penelitiannya bahwa pergeseran bahasa umumnya mengacu pada proses penggantian satu bahasa dengan bahasa lain dalam repertoire linguistik suatu masyarakat.

Penggunaan bahasa yang bergeser di Kota Banjarbaru salah satunya nampak pada penggunaan kata sapaan oleh generasi milenial Banjar yang berbeda dengan generasi sebelumnya. Menurut Yule dalam makalah yang ditulis (Rusbiyantoro, 2014, hal. 276) dijelaskan bahwa kata sapaan sebagai kata atau frasa yang digunakan oleh pembicara untuk menyapa kawan bicaranya, baik dalam bahasa lisan maupun bahasa tulis.

Generasi milenial akibat kemajuan teknologi lebih menyukai bahasa yang memiliki prestise begitu juga dalam memilih kata sapaan. Hal ini mengakibatkan kata sapaan yang digunakan bergeser. Misalnya ketika para generasi milenial Banjar menyapa orang tua laki-laki mereka lebih memilih menggunakan kata abi, ayah, dan papa ketimbang abah.

Adanya fenomena pergeseran bahasa seperti contoh di atas terjadi karena sikap kesetiaan terhadap bahasa berkurang. Pergeseran bahasa menyangkut masalah mobilitas penutur, di mana sebagai akibat dari perpindahan penutur atau para penutur itu dapat menyebabkan terjadinya pergeseran bahasa, seperti penutur yang tadinya menggunakan bahasa ibu kemudian menjadi tidak menggunakannya lagi (Chaer \& Agustina, 2010, hal. 142).

Penelitian tentang kata sapaan sebelumnya sudah pernah diteliti. Nengsih (2013) meneliti tentang Variasi Panggilan dalam Tutur Sapa Masyarakat Banjar dan Rianto (2013) meneliti tentang Pergeseran Bentuk Kata Sapaan Pada Masyarakat Jawa di Desa Rejo Agung, Kecamatan Semboro Kabupaten Jember. Dalam penelitiannya Nengsih membahas tentang kategori dan variasi sapaan bahasa Banjar dan penggunaannya. Sementara itu, Rianto, dkk. membahas pergeseran kata sapaan masyarakat Jawa di Desa Rejoagung.

Penelitian yang dilakukan peneliti mempunyai persamaan dengan penelitian sebelumnya, yaitu sama-sama meneliti kata sapaan. Meskipun sama-sama meneliti kata sapaan, tetapi objek yang digunakan berbeda. Penelitian yang peneliti lakukan menitikberatkan pada objek generasi milenial. Hal ini karena di wilayah Kota Banjarbaru penggunaan kata sapaan oleh generasi milenial dengan lawan tuturnya sudah bergeser dari bahasa ibunya, yaitu bahasa Banjar. Atas dasar itu penelitian yang berjudul Pergeseran Penggunaan Kata Sapaan oleh Generasi Milenial Banjar di Kota Banjarbaru perlu dilakukan.

Masalah yang diteliti dalam penelitian ini adalah (1) bagaimana pergeseran bentuk kata sapaan yang digunakan oleh generasi milenial Banjar di Kota Banjarbaru dan (2) faktor-faktor apa sajakah yang mempengaruhi pergeseran kata sapaan yang digunakan oleh generasi milenial Banjar di Kota Banjarbaru? 
Tujuan penelitian untuk (1) mendeskripsikan pergeseran bentuk kata sapaan yang digunakan oleh generasi milenial Banjar di Kota Banjarbaru dan (2) mendeskripsikan faktor-faktor yang memengaruhi pergeseran kata sapaan yang digunakan oleh generasi milenial Banjar di Kota Banjarbaru.

\section{TEORI DAN METODOLOGI}

Pergeseran bahasa menyangkut masalah penggunaan bahasa oleh seorang penutur atau kelompok penutur yang terjadi akibat perpindahan dari satu masyarakat tutur ke masyarakat tutur yang lain, yaitu masyarakat tutur yang baru (Amin \& Suyanto 2017, hal. 16)

Hal ini selaras dengan yang dikemukakan (Chaer \& Agustina, 2010, hal. 142) bahwa masalah pergeseran bahasa menyangkut masalah penggunaan bahasa oleh seorang penutur atau kelompok tutur yang bisa terjadi sebagai akibat perpindahan dari satu masyarakat tutur ke masyarakat tutur yang lain.

Pergeseran bahasa merupakan hasil dari proses pemilihan bahasa dalam jangka waktu yang sangat panjang (Fasold, 1984, hal. 213). Sementara itu, menurut (Rafiek, 2010, hal. 84) pergeseran bahasa (language shift) adalah perubahan secara tetap dalam pilihan bahasa seseorang untuk keperluan sehari-hari, terutama akibat migrasi.

Pergeseran bahasa terjadi apabila masyarakat bahasa itu mulai meninggalkan bahasa yang digunakan dan beralih menggunakan bahasa lainnya. Menurut Edward dalam (Rafiek, 2010, hal. 85) salah satu gejala pergeseran bahasa adalah berkurangnya jumlah penutur usia muda dari bahasa tersebut dan mereka cenderung menggunakan bahasa yang dianggap lebih berprestise.

Pergeseran bahasa biasanya terjadi di negara, daerah, atau wilayah yang memberi harapan untuk kehidupan sosial ekonomi yang lebih baik, sehingga mengundang imigran atau transmigran untuk mendatanginya (Chaer \& Agustina, 2010, hal. 144).

Faktor-faktor yang menyebabkan pergeseran bahasa menurut (Fasold, 1984) ada empat, yaitu prestise, urbanisasi sikap bahasa, dan transmisi bahasa. Sementara itu, Hoffmann dalam (Rafiek, 2010, hal. 85) menjelaskan ada lima penyebab pergeseran bahasa, yaitu migrasi, industrialisasi, urbanisasi, prestise, dan penggunaan sebagai bahasa di sekolah.

Untuk menguji penggunaan bahasa pada komunitas tutur diperlukan teori ranah. Menurut (Fishman, 1972, hal. 442) ranah adalah gambaran abstrak sosial budaya dari topik komunikasi, hubungan antarkomunikator, dan tempat terjadinya peristiwa komunikasi sesuai dengan struktur sosial komunitas penutur. Ada empat ranah untuk menguji penggunaan bahasa komunitas tutur. Keempat ranah itu menurut (Fishman, 1972, hal. 213), yaitu keluarga, ketetanggaan, agama, dan kerja. Sementara itu, menurut Fasold (dalam Purba, 2017, hal. 258) dijelaskan bahwa pergeseran bahasa dipengaruhi oleh adanya bilingualism, industrialisme, bahasa asing yang lebih prastise, urbanisasi, atau migrasi, dan generasi.

Hal lain, (Sumarsono \& Paina, 2002, hal. 266) menambahkan ranah yang sebelumnya menjadi tujuh ranah penggunaan bahasa pada komunitas tutur, yaitu keluarga, kekariban, ketetanggaan, pendidikan, agama, transaksi, dan pemerintah.

Penelitian yang dilakukan peneliti menggunakan metode deskriptif kualitatif dengan pendekatan sosiolinguistik. Menurut (Moleong, 2010, hal. 6), penelitian kualitataif 
adalah upaya untuk menyajikan dunia sosial dan perspektifnya dari segi konsep, perilaku, persepsi, dan persoalan tentang manusia yang diteliti. Sementara itu, penelitian yang dilakukan bersifat deskriptif karena di dalam penelitian yang dilakukan analisis yang dilakukan berupa kata-kata, kalimat, gambar, dan bukan angka. Hal ini sama dengan apa yang diungkapkan oleh Sutopo (dalam Wahidah, dkk. 2017).

Data yang digunakan dalam penelitian ini berupa kata sapaan yang digunakan oleh generasi milenial Banjar di Banjarbaru. Sumber data dalam penelitian berupa tuturan yang disampaikan oleh generasi milenial Banjar di Banjarbaru.

Teknik pengumpulan data yang digunakan dalam penelitian ini adalah metode simak dan cakap. Teknik dasar yang digunakan dalam metode simak dengan teknik sadap, yaitu menyadap penggunaan kata sapaan oleh generasi milenial Banjar pada ranah keluarga, kekerabatan, dan ketetanggaan. Teknik simak lanjutan yang digunakan peneliti dengan cara teknik Simak Libat Cakap (SLC) dan teknik Simak Bebas Libat Cakap (SBLC). Sementara itu, teknik cakap dilakukakan dengan cara wawancara langsung kepada informan. Teknik dasar yang digunakan dalam teknik cakap yaitu teknik pancing. Teknik pancing dilakukan dengan cara memancing informan berbicara dengan menggunakan kata-kata sapaan. Selain itu, dilakukan dengan teknik lanjutan cakap semuka, peneliti bercakap-cakap dengan informan untuk berusaha menggali data dengan teknik rekam dan catat.

Setelah data terkumpul kemudian dilakukan analisis data. Analisis data dilakukan dengan metode padan dan teknik lanjutan teknik Pilah Unsur Penentu (PUP). Data yang sudah dikumpulkan diklasifikasi dan dianalisis berdasarkan teori bentuk sapaan bahasa Banjar. Tahap analisis data dilakukan dengan cara (1) menganalisis bagaimana bentuk pergeseran kata sapaan yang digunakan oleh generasi milenial Banjar di Kota Banjarbaru pada ranah kekeluargaan, kekerabatan, dan ketetanggaan; (2) menganalisis karakteristik pergeseran kata sapaan yang digunakan oleh generasi milenial Banjar di Kota Banjarbaru pada ranah kekeluargaan, kekerabatan, dan ketetanggaan; dan (3) menganalisis faktorfaktor yang memengaruhi pergeseran kata sapaan yang digunakan oleh generasi milenial Banjar di Kota Banjarbaru pada ranah kekeluargaan, kekerabatan, dan ketetanggaan.

Setelah data dianalisis kemudian data disajikan dengan menggunakan metode penyajian informal. Metode penyajian informal adalah perumusan dengan kata-kata biasa (Sudaryanto, 1993, hal. 31).

\section{HASIL DAN PEMBAHASAN}

Kata sapaan merupakan kata yang digunakan oleh para penutur untuk menyapa lawan tutrnya. Setiap masyarakat menggunakan kata sapaan sesuai dengan pilihannya masing-masing. Generasi milenial Banjar di kota Banjarbaru merupakan generasi muda Banjar yang tinggal di kota Banjarbaru tetapi seiring perkembangan mereka memilih menggunakan sapaan bahasa Indonesia dan bahasa asing. Hal ini mengakibatkan kata sapaan bahasa Banjar tergeser dengan bahasa lain. Berikut bentuk dan karakteristik kata sapaan bahasa Banjar beserta kata sapaan yang menggantikan dalam ranah keluarga, ketetanggan, dan keakraban serta faktor-faktor yang mempengaruhinya. 


\section{Pergeseran penggunaan Kata Sapaan oleh Generasi Milenial Banjar dalam Ranah Keluarga}

Penggunaan kata sapaan oleh generasi milenial Banjar di kota Banjarbaru ketika berbicara dengan keluarga baik itu keluarga langsung maupun tidak langsung mengalami pergeseran. Keluarga langsung yang dimaksud di sini adalah keluarga yang disebabkan oleh silsilah garis keturunan. Sedangkan keturunan tak langsung adalah hubungan yang disebabkan oleh adanya ikatan perkawinan. Hal ini karena generasi milenial Banjar lebih memilih kata sapaan bahasa Indonesia dan kata sapaan yang berasal dari bahasa asing. Berikut bentuk kata sapaan yang digunakan oleh generasi milenial Banjar ketika berbicara dengan keluarga.

Tabel 1. Bentuk Pergeseran Kata Sapaan yang digunakan oleh generasi Milenial Banjar dalam Ranah Keluarga Langsung

\begin{tabular}{|c|c|c|}
\hline Sapaan Bahasa Banjar & Sapaan Penggeser & Lawan Tutur \\
\hline Éntah & Kai, Abahnya Datu & orang tua laki-laki kakek \\
\hline Abah & Ayah, Papa, Bapak, Abi & orang tua laki-laki \\
\hline Mamak, Uma, Ma & Ibu, Mama, Umi, Bunda & orang tua perempuan \\
\hline Gulu & Paman, Bibi & $\begin{array}{l}\text { saudara bapak/ibu yang nomor } \\
\text { dua dari yang tertua }\end{array}$ \\
\hline Pérang, Tangah & Paman & $\begin{array}{l}\text { saudara bapak/ibu khusus laki- } \\
\text { laki nomor tiga }\end{array}$ \\
\hline Mang, Amang & Man, Paman, Om & adik laki-laki dari ayah atau ibu \\
\hline Su aluh, Ma aluh & Acil & $\begin{array}{l}\text { adik perempuan bapak/ibu } \\
\text { bungsu }\end{array}$ \\
\hline
\end{tabular}

Éntah

Kata sapaan éntah merupakan kata sapaan yang biasanya digunakan oleh masyarakat Banjar untuk menyapa orang tua laki-laki dari kakek. Namun seiring perkembangan zaman kata sapaan itu sudah bergeser. Generasi milenial ketika menyapa orang tua dari kakek tidak menggunakan kata tersebut. Mereka lebih memilih menggunakan kata datu. Kata sapaan éntah bahkan sudah tidak dikenal lagi oleh para generasi milenial karena orang yang disapa yaitu orang tua dari kakek jarang ditemui.

\section{Abah}

Kata sapaan Abah biasanya digunakan oleh masyarakat Banjar untuk memanggil orang tua laki-laki kita. Namun, penggunaan kata sapaan $A b a h$ di era milenial sudah bergeser. Generasi milenial lebih memilih menggunakan kata sapaan Ayah, Papa, dan Abi. Dalam Majalah Pembinaan Bahasa Indonesia Volume 5-8 terbitan 1984, kata sapaan Papa yang dipilih oleh para generasi milenial merupakan kata sapaan yang berasal dari Belanda 'pappie' atau pappaatje. Kata sapaan itu digunakan pada masa kolonial Belanda dan digunakan oleh orang Belanda yang berpendidikan (Isnaeni, 2019). Sementara itu, kata sapaan $A b i$ biasanya digunakan oleh para generasi milenial yang Islami. Kata sapaan $A b i$ berasal dari bahasa Arab. 


\section{Mamak, Uma, Ma}

Kata sapaan Mamak biasanya digunakan oleh masyarakat Banjar untuk memanggil orang tua perempuan. Namun, penggunaan kata Mamak di era milenial sudah bergeser. Generasi milenial lebih memilih menggunakan kata mama, ibu, bunda, dan umi. Sama halnya dengan kata sapaan papa, kata sapaan mama juga berasal dari Belanda. Kata Mama berasal dari bahasa Belanda mammie atau mammaatje. Sama halnya juga dengan kata sapaan $A b i$, kata sapaan $U m i$ biasanya digunakan oleh para generasi milenial yang Islami. Kata sapaan Umi berasal dari bahasa Arab.

\section{Mang, Amang}

Mang, Amang merupakan kata sapaan yang biasanya oleh masyarakat Banjar digunakan untuk menyapa adik laki-laki dari ayah atau ibu. Di era milenial penggunaan kata mang, amang sudah bergeser. Generasi muda milenial memilih menggunakan kata paman dan om ketika menyapa adik laki-laki dari ayah atau ibu. Kata sapaan paman dan om tidak hanya digunakan untuk menyapa adik laki-laki dari ayah atau ibu, tetapi juga digunakan untuk menyapa orang laki-laki yang usianya lebih tua.

\section{Gulu}

Kata sapaan gulu merupakan kata sapaan yang digunakan oleh masyarakat Banjar untuk menyapa saudara bapak/ibu yang nomor dua dari yang tertua. Kata sapaan gulu bisa digunakan untuk menyapa saudara laki-laki dan perempuan. Namun, di era milenial penggunaan kata gulu sudah bergeser. Generasi muda milenial memilih menggunakan kata sapaan paman ketika berbicara dengan saudara bapak/ibu laki-laki dan memilih kata bibi untuk menyapa saudara bapak/ibu perempuan.

\section{Pérang, Tangah}

Kata sapaan pérang, tangah digunakan oleh masyarakat Banjar untuk menyapa saudara bapak/ibu khusus laki-laki nomor tiga. Kata sapaan itu bergeser ketika digunakan oleh generasi milenial. Mereka justru lebih memilih menggunakan kata paman ketika berkomunikasi dengan mereka.

Tabel 2. Bentuk Pergeseran Kata Sapaan yang digunakan oleh Generasi Milenial Banjar dalam Ranah Keluarga Tidak Langsung

\begin{tabular}{llc}
\hline Sapaan Bahasa Banjar & \multicolumn{1}{c}{ Sapaan Penggeser } & Lawan Tutur \\
Laki & Kak, Abi, Papa, Ayah, & Suami \\
Bini & Dek, Umi, Mama, Bunda & Istri \\
Pawarangan & Bapak, Ibu/mama, papa & Orang tua dari suami \\
Antin & Kakak, kak & Ipar yang paling tua \\
\hline
\end{tabular}

\section{Laki}

Kata sapaan laki merupakan kata sapaan bahasa Banjar yang digunakan oleh masyarakat Banjar ketika menyapa suaminya. Namun, seiring perkembangannya kata laki bergeser dalam penggunaannya. Kata laki tergeser dengan kata kak, abi, papa, dan ayah yang dipengaruhi bahasa Indonesia dan bahasa asing. Kata-kata tersebut dipilih oleh seorang istri untuk membahasakan anak-anak mereka. Sehingga kata yang dipilih bukan 
suami. Kata laki dalam bahasa Banjar bisa memiliki makna laki-laki yang menunjukkan jenis kelamin seseorang.

\section{Bini}

Kata sapaan bini merupakan kata sapaan yang biasanya digunakan masyarakat Banjar untuk menyapa istrinya. Selain kata bini, ada juga masyarakat Banjar yang menggunakan kata umanya. Namun, seiring perkembangan zaman kata bini dan umanya bergeser menjadi dek, umi, mama, dan bunda.

\section{Pawarangan}

Kata sapaan pawarangan merupakan kata sapaan yang digunakan oleh masyarakat Banjar untuk menyapa orang tua dari suami. Namun, di era milenial kata tersebut sudah bergeser digantikan dengan kata bahasa Indonesia bapak atau ibu, abah atau mama sesuai dengan sapaan yang digunakan oleh suami atau istri sebelum menikah.

\section{Antin}

Kata sapaan antin merupakan kata sapaan yang digunakan masyarakat Banjar untuk menyapa ipar yang paling tua. Kata tersebut di era milenial bergeser menjadi man, paman ketika iparnya berjenis kelamin laki-laki, bergeser menjadi cil, bibi ketika iparnya perempuan.

\section{Pergeseran Penggunaan Kata Sapaan oleh Generasi Milenial Banjar dalam Ranah Ketetanggaan}

Kata sapaan yang digunakan oleh generasi milenial dalam ranah ketetanggaan pada era milenial mengalami pergeseran. Berikut kata sapaan yang digunakan ketika berbicara dengan lawan tutur yaitu tetangga.

Tabel 3. Bentuk Pergeseran Kata Sapaan yang digunakan oleh Generasi Milenial Banjar dalam Ranah Ketetanggaan

\begin{tabular}{|c|c|c|}
\hline $\begin{array}{l}\text { Kata Sapaan Bahasa } \\
\text { Banjar }\end{array}$ & Kata Sapaan Penggeser & Lawan Tutur \\
\hline Amang, julak laki & Paman, & $\begin{array}{l}\text { Laki-laki yang lebih tua } \\
\text { sebaya ayah }\end{array}$ \\
\hline julak bini & Bibi, Tante & $\begin{array}{l}\text { perempuan yang lebih tua } \\
\text { sebaya ibu }\end{array}$ \\
\hline$A a$ & Kakak & $\begin{array}{l}\text { tetangga laki-laki yang lebih } \\
\text { tua dari penutur }\end{array}$ \\
\hline Ading & Adek, Dek & $\begin{array}{l}\text { tetangga laki-laki atau } \\
\text { perempuan muda (anak- } \\
\text { anak) }\end{array}$ \\
\hline Pa anang & Pak, Om & laki-laki yang sebaya ayah \\
\hline Aluh & Nak & anak perempuan \\
\hline Anang & Nak & Anak laki-laki \\
\hline
\end{tabular}

Tabel 3 di atas menunjukkan kata sapaan yang digunakan oleh generasi milenial di Kota Banjarbaru. Kata sapaan yang berupa kata dari bahasa asli bahasa Banjar seperti 
amang, acil, $a a$, dan ading bergeser. Bahkan penggunaan kata $\mathrm{Pa}$ anang sudah tidak digunakan lagi oleh generasi milenial. Dari tabel 2 diketahui bahwa generasi milenial lebih memilih menggunakan bahasa Indonesia.

\section{Amang}

Amang, julak laki merupakan kata sapaan yang digunakan oleh masyarakat Banjar untuk menyapa tetangga laki-laki yang sudah berkeluarga. Di era milenial penggunaan kata amang dan julak laki sudah bergeser. Generasi muda milenial memilih menggunakan kata sapaan 'paman dan ada juga yang menyapa bapak + nama, bapak + nama anak pertama ketika menyapa saudara laki-laki yang lebih tua.

\section{Julak Bini}

Acil, Cil, julak bini merupakan kata sapaan yang digunakan oleh masyarakat Banjar untuk menyapa tetangga perempuan yang sudah berkeluarga. Di era milenial penggunaan kata acil, cil, julak bini sudah bergeser. Generasi muda milenial memilih menggunakan kata sapaan bibi, tante ketika menyapa saudara perempuan yang lebih tua atau sebaya ibu.

Aa

$A a$ merupakan kata sapaan yang digunakan oleh masyarakat Banjar untuk menyapa tetangga laki-laki yang belum berkeluarga. Di era milenial penggunaan kata $A a$ sudah bergeser. Generasi muda milenial Banjar memilih menggunakan kata sapaan kakak ketika menyapa tetangga laki-laki yang belum berkeluarga. Namun, kadang-kadang sapaan ini juga digunakan oleh generasi milenial untuk menyapa anak kecil sebagai bentuk sapaan untuk mengajari anak mereka berbahasa santun kepada teman anaknya yang usianya sebaya atau lebih tua.

\section{Ading}

Ading merupakan kata sapaan yang digunakan oleh masyarakat Banjar untuk menyapa tetangga laki-laki dan perempuan yang masih muda. Di era milenial penggunaan kata Ading sudah bergeser. Generasi muda milenial memilih menggunakan kata sapaan adik, dek ketika menyapa tetangga laki-laki dan perempuan yang lebih muda.

\section{Pa anang}

$P a$ anang merupakan kata sapaan yang digunakan oleh masyarakat Banjar untuk menyapa tetangga laki-laki yang usianya sebaya ayah. Di era milenial kata sapaan $P a$ anang bergeser berganti dengan kata Pak, $\mathrm{Om}$.

\section{Aluh}

Aluh merupakan kata sapaan yang digunakan oleh masyarakat Banjar ketika menyapa tetangga perempuan yang usianya masih muda atau anak-anak. Namun, seiring perkembangannya kata sapaan aluh oleh generasi milenial Banjar sudah jarang digunakan ketika menyapa mereka lebih memilih dengan sapaan nak. 


\section{Anang}

Anang merupakan kata sapaan yang biasanya digunakan oleh masyarakat Banjar untuk menyapa tetangga laki-laki yang usianya masih muda atau anak-anak. Namun, sama halnya ketika menyapa anak perempuan yang usianya lebih muda, generasi milenial sekarang lebih memilih menggunakan sapaan nak ketika menyapa anak laki-laki. Kata sapaan anang oleh masyarakat Banjar juga biasa digunakan untuk menyapa orang tua laki-laki. Namun sekarang generasi milenial Banjar lebih memilih menyapa dengan menggunakan sapaan pak atau pak + nama anak.

\section{Pergeseran penggunaan Kata Sapaan oleh Generasi Milenial Banjar dalam Ranah Kekerabatan}

Seperti halnya penggunaan kata sapaan pada ranah keluarga dan ketetanggaan, penggunaan kata sapaan oleh generasi milenial Banjar pada ranah kekerabatan juga bergeser. Pergeseran itu tampak ketika mereka menyapa teman akrab. Berikut bentuk kata sapaan yang digunakan oleh generasi muda di era milenial.

Tabel 4. Bentuk Pergeseran Kata Sapaan yang digunakan oleh Generasi Milenial Banjar dalam Ranah Kekerabatan

\begin{tabular}{ll}
\hline \multicolumn{1}{c}{ Kata sapaan } & \multicolumn{1}{c}{ Makna } \\
Bro & Panggilan kepada teman akrab laki-laki \\
Bos & Panggilan kepada teman akrab secara berlebihan \\
Abah + nama anak & Bapak + nama anak \\
umanya + nama anak & Mamanya + nama anak, ibu + nama anak \\
Yank, say & Panggilan kepada teman akrab yang dianggap spesial \\
\hline
\end{tabular}

\section{Bro}

Kata sapaan bro merupakan kata sapaan yang digunakan oleh para generasi muda di era milenial ketika berbicara dengan teman akrab laki-lakinya. Sapaan bro berasal dari bahasa Inggris 'brother' yang berarti saudara laki-laki. Proses pembentukan sapaan brother menjadi bro dilakukan dengan cara pemenggalan suku kata awal atau bunyi awal.

Bos

Sesuai dengan KBBI daring, kata bos mempunyai makna orang yang berkuasa mengawasi dan memberi perintah kepada para karyawan; pemimpin atau majikan. Kata sapaan bos oleh generasi milenial digunakan untuk menyapa teman akrab mereka secara berlebihan. Biasanya ditujukan kepada teman yang lagaknya seperti pimpinan atau memang memiliki kuasa.

\section{Abah+nama anak}

Kata sapaan abah+nama anak merupakan kata sapaan yang digunakan oleh para generasi muda di era milenial Banjar untuk menyapa teman laki-laki sebaya atau lebih muda yang sudah akrab. 


\section{Umanya+ nama anak}

Hampir sama dengan kata abah+ nama anak, kata sapaan umanya+nama anak juga digunakan untuk oleh para generasi muda di era milenial Banjar untuk menyapa teman akrab mereka. Namun, kata tersebut digunakan untuk menyapa teman perempuan yang sebaya atau lebih muda dan sudah akrab.

\section{Yang, say}

Kata sapaan yang atau say berasal dari bahasa Indonesia, yaitu sayang yang artinya orang yang dicintai. Kata sapaan yang atau say digunakan oleh para generasi muda di era milenial Banjar untuk menyapa seseorang yang dianggap spesial atau orang yang dicintai.

\section{Faktor-Faktor yang Memengaruhi Pergeseran Penggunaan Kata Sapaan oleh Generasi Milenial Banjar di Kota Banjarbaru}

Hasil penelitian menunjukkan ada beberapa faktor yang memengaruhi Penggunaan Kata Sapaan oleh Generasi Milenial Banjar di Kota Banjarbaru. Faktor-faktor yang memengaruhi antara lain sebagai berikut.

2.1 Urbanisasi

Urbanisasi adalah perpindahan penduduk dari desa ke kota. Adanya urbanisasi mengakibatkan pergeseran penggunaan kata sapaan. Ketika masyarakat desa bercampur dengan masyarakat kota akan mengakibatkan campur aduk dalam pemakaian bahasa. Peristiwa urbanisasi dapat memengaruhi penggunaan bahasa seseorang. Misalnya kata $i b u$ yang berasal dari bahasa Indonesia digunakan oleh generasi milenial Banjar untuk menyapa orang tua perempuan sehingga menggeser kata uma, mamak. Peristiwa urbanisasi ini menyebabkan pergeseran bahasa karena dipengaruhi oleh sikap bahasa penuturnya. Ketika mereka memiliki sikap positif tentu mereka akan terus mempertahankan kata sapaan daerahnya ketika berkomunikasi dengan lawan tutur yang memiliki suku yang sama.

\subsection{Adanya bahasa lain, yaitu bahasa Indonesia dan bahasa asing}

Faktor hadirnya bahasa Indonesia sangat memengaruhi pergeseran bahasa. Penggunaan bahasa Indonesia dalam keluarga sangat memengaruhi dalam penggunaan sapaan oleh generasi milenial. Bahasa Indonesia yang merupakan bahasa komunikasi yang digunakan antaretnis dianggap memiliki prestise tinggi dibandingkan bahasa daerah. Oleh karena itu, para generasi milenial Banjar lebih memilih menggunakan kata sapaan bahasa Indonesia. Misalnya kata ibu dan ayah lebih mereka pilih daripada kata mamak dan abah.

Bahasa asing juga digunakan oleh generasi milenial Banjar ketika menyapa orang lain. Tidak hanya di ranah kekerabatan, bahkan di ranah keluargan pun juga menggunakan kata sapaan bahasa asing. Kata asing yang digunakan itu misalnya untuk menyapa teman akrab berupa kata sapaan bro. Selain itu, kata sapaan mama dan papa yang berasal dari bahasa Belanda dan umi dan abi yang berasal dari bahasa Arab juga digunakan. Hal ini 
menjadikan kata sapaan bahasa Banjar bergeser dengan adanya bahasa Indonesia dan bahasa asing.

\subsection{Adanya Alih Generasi}

Masyarakat yang tinggal di suatu wilayah biasanya sudah mengenal variasi bahasanya. Ketika orang tua tidak lagi menggunakan bahkan tidak lagi mau megajarkan bahasa daerah kepada anak-anaknya maka variasi bahasa akan berubah tergantikan dengan yang baru. Kata éntah oleh masyarakat Banjar digunakan untuk menyapa orang tua laki-laki dari kakek. Namun, karena kebanyakan orang tua laki-laki dari kakek sudah meninggal, kata tersebut tidak lagi digunakan. Generasi milenial hanya mengenal kata kai dan datu saja meskipun orang tua dari kakek laki-laki.

Pergeseran bahasa Banjar terlihat dari generasi milenial menggunakan kata sapaan ketika berkomunikasi. Pergeseran terlihat ketika mereka berkomunikasi dengan teman akrab, tetangga, bahkan dengan keluarga sendiri. Penggunaan kata sapaan justru paling banyak bergeser ketika mereka berkomunikasi dengan keluarga sendiri. Pilihan bahasa Indonesia dan bahasa asing lebih dipilih daripada bahasa Banjar. Faktor perpindahan, prestise, kemajuan iptek, dan alih generasi merupakan faktor yang mempengaruhi pergeseran kata sapaan oleh generasi milenial Banjar di Banjarbaru.

Dari hasil penelitian Nengsih (2013) yang berjudul Variasi Panggilan dalam Tutur Sapa Masyarakat Banjar memperlihatkan tentang variasi panggilan tutur sapa masyarakat Banjar menunjukkan sistem yang mencerminkan suatu pola tingkah laku dan sikap para anggota masyarakatnya. Panggilan untuk menyebut orang kedua digunakan dengan tujuan dan maksud berbeda. Penggunaan variasi panggilan masyarakat Banjar dipengaruhi perbedaan situasi, usia, hubungan sosial, dan status sosial. Selain itu, dipengaruhi faktor kesantunan dan rasa hormat.

Temuan selanjutnya, Rianto (2013) dalam makalahnya yang berjudul Pergeseran Bentuk Kata Sapaan Pada Masyarakat Jawa di Desa Rejo Agung, Kecamatan Semboro Kabupaten Jember. Sementara itu, hasil penelitian Rianto, dkk. menunjukkan bahwa telah terjadi pergeseran penggunaan bentuk kata sapaan pada masyarakat Jawa, artinya masyarakat Jawa lebih memilih menggunakan kata sapaan bahasa Indonesia. Keluarga PNS yang memiliki status sosial lebih tinggi di masyarakat dominan bergeser dalam penggunaan kata sapaan yang dipengaruhi oleh perkembangan zaman, ipteks, dan sosial budaya.

Dari kedua penelitian ini ada persamaan dengan penelitian yang dilakukan peneliti, yaitu objeknya kata sapaan. Namun, penelitian yang peneliti lakukan ada perbedaannya dengan yang sudah dilakukan Nengsih. Penelitian Nengsih hanya menemukan kategori kata sapaan saja dan penggunaannya di masyarakat. Sementara dalam penelitian yang dilakukan peneliti, menemukan pergeseran penggunaan kata sapaan yang digunakan oleh generasi milenial Banjar di Kota Banjarbaru. Pergeseran bahasa Banjar terlihat dari generasi milenial menggunakan kata sapaan ketika berkomunikasi. Pergeseran terlihat ketika mereka berkomunikasi dengan teman akrab, tetangga, bahkan dengan keluarga sendiri. Penggunaan kata sapaan justru paling banyak 
bergeser ketika mereka berkomunikasi dengan keluarga sendiri. Pilihan bahasa Indonesia dan bahasa asing lebih dipilih daripada bahasa Banjar. Faktor perpindahan, prestise, kemajuan iptek, dan alih generasi merupakan faktor yang mempengaruhi pergeseran kata sapaan oleh generasi milenial Banjar di Banjarbaru.

\section{SIMPULAN}

Berdasarkan hasil penelitian dapat disimpulkan bahwa masyarakat Banjar memiliki kata sapaan yang bervariasi. Hal ini didasarkan pada tingkat usia, status sosial dalam masyarakat, dan kesantunan. Namun, seiring perkembangan zaman adanya pengaruh iptek, perpindahan, adanya pengaruh bahasa lain, dan alih generasi serta ekonomi membuat kata sapaan bahasa Banjar bergeser. Generasi milenial lebih memilih bahasa Indonesia dan bahasa asing daripada bahasa Banjar. Kata sapaan pawarangan yang digunakan oleh masyarakat Banjar untuk menyapa orang tua dari suami bergeser ketika digunakan oleh generasi milenial Banjar. Ketika menyapa orang tua dari suami tidak lagi menggunakan kata sapaan pawarangan tetapi menggunakan bahasa Indonesia bapak atau ibu, abah atau mama sesuai dengan sapaan yang digunakan oleh suami atau istri sebelum menikah. Hasil temuan ini memiliki kesamaan dengan penelitian sebelumnya bahwa masyarakat Jawa ketika menyapa orang lain mereka juga memilih bahasa Indonesia. Namun, yang membedakan dari hasil penelitian sebelumnya masyarakat Jawa tidak memilih bahasa asing.

Fenomena pergeseran bahasa khususnya pada penggunaan kata sapaan tentu dikhawatirkan akan membuat punah bahasa Banjar. Oleh karena itu, hasil penelitian ini diharapkan dapat menjadi dasar untuk pengambilan kebijakan pemerintah dalam rangka pemertahanan bahasa.

\section{RFERENSI}

Amin, M. F. \& S. (2017). Pergeseran dan pemertahanan bahasa ibu dalam ranah rumah tangga migran di Kota Semarang. Nusa, 12, 15-26.

Chaer, A. \& L. A. (1995). Sosiolinguistik perkenalan awal. Jakarta: Rineka Cipta.

Chaer, A. \& L. A. (2010). Sosiolinguistik perkenalan awal. Jakarta: Rineka Cipta.

Fasold, R. (1984). The sosiolinguistics of society. New York: Blackwell.

Fishman, J. (1972). The sociology of language. Rowley: Newbury.

Isnaeni, H. F. (2019). Sejarah panggilan papah dan mamah. Retrieved from google.co.id/amp/s/historia.id

Moleong, L. (2010). Metode penelitian kualitatif. Bandung: Rosdakarya.

Nengsih, S. W. (2013). Variasi panggilan dalam tutur sapa masyarakat Banjar. Bunga Rampai Hasil Penelitian Kebahasaan.

Purba, G. (2017). Pergeseran kata sapaan dalam bahasa Simalungun di Kecamatan Labuhan Deli. Basastra, 6 (4). https://doi.org/https://doi.org/10.24114/bss.v6i4.9027 
Putri, N. W. (2018). Pergeseran bahasa daerah Lampung pada masyarakat kota Bandar Lampung. Prasasti: Journal of Linguistcs, 3, 83-97.

Rafiek, M. (2010). Dasar-dasar sosiolinguistik. Jogjakarta: Pustaka Prisma.

Rianto, S. dkk. (2013). Pergeseran bentuk kata sapaan pada masyarakat Jawa Di Desa Rejoagung, Kecamatan Semboro, Kabupaten Jember. Publika Budaya, 1 (1).

Rusbiyantoro, W. (2014). Kesantunan melalui pemilihan kata sapaan dalam bahasa Melayu Kutai: suatu kajian sosiopragmatik. Prosiding Seminar Nasional Prasasti, 275283. https://doi.org/https://doi.org/10.20961/pras.v0i0

Sudaryanto. (1993). Metode dan aneka teknik analisis berbahasa: pengantar penelitian wahana kebudayaan secara linguistis. Yogyakarta: Wacana University Press.

Sumarsono. (2011). Sosiolinguistik. Yogyakarta: Pustaka Pelajar.

Sumarsono \& Paina, P. (2002). Sosiolinguistik. Yogyakarta: Penerbit Sabda.

Wahidah, Baiq Yulia Kurnia, dkk. (2017). Pilihan kode bagi siswa di Pesantren Ulil Albab (kajian sosiolinguistik). Prasasti: Journal of Linguistcs, 2 (2).

https://doi.org/https://doi.org/10.20961/prasasti.v212.1222 